\title{
THE CONSTITUTIONS OF THE STATE OF FRANKLIN, THE INDIAN STREAM REPUBLIC AND THE STATE OF DESERET
}

\author{
Edwin R. Keedy $\dagger$
}

\section{State of FrankLin}

North Carolina adopted its first Constitution in 1776. At that time its territory extended westward to the Mississippi River. In June, 1784, the General Assembly voted to cede the territory west of the Cumberland Mountains to the Continental Congress. ${ }^{1}$ As a direct and immediate result of this action ${ }^{2}$ delegates from three counties west of the mountains, ${ }^{3}$ at a convention held in Jonesborough on August 23, 1784, declared these counties to be independent of North Carolina ${ }^{4}$ and voted for the creation of a new state, the State of Franklin. ${ }^{5}$ In December of the same year a convention, also held at Jonesborough, adopted a formal Declaration of Independence ${ }^{6}$ and a provisional Con-

$\dagger$ Professor of Law Emeritus, University of Pennsylvania.

1. Haywood, Civil and Political History of Tennessee 148 (1823). The Continental Congress had urged Virginia and North Carolina to cede their western lands, but it is generally agreed that the cession by North Carolina was for the benefit of land speculators. AbERNEThy, From Frontier to Plantation in TENNESSEE 67 (1932).

2. AgERNETHY, op. cit. supra note 1 , at 57 .

3. Washington, Sullivan and Greene.

4. Wilitams, The Lost State of Frankiln 29 (1924).

5. ABERnethy, op. cit. supra note 1 , at 69 . The North Carolina Assembly repealed the act of cession in November, 1784. RAMsey, AnNals of Tennessee 290 (1853).

\section{Declaration of Independence}

"Your committee appointed to collect and adjust the reason which impels us to declare ourselves Independent of North Carolina Report as follows (to wit) Whereas we the freedmen inhabitants of part of the Country included in the limits of an Act of North Carolina Ceding certain vacant Territory to Congress; have declared ourselves Independent of North Carolina a decent respect to the opinions of mankind make it proper that we should manifest to the world the reasons which Induced us to a declaration, which are as follows.-

"First. That the Constitution of North "Carolina declares that it shall be Justifiable to erect New States Westward when ever the Consent of the Legislative shall Countenance it, \& this Consent is implied we conceive in the Cession act which has thrown us into such a citation that the influance of the Law in common cases became almost a nullity \& incriminal Jurisdiction had intirely seased which reduced us to the verge of anarchy.

"2nd.-The Assembly of North Carolina have detained a Certain quantity of Goods, which was procured to satisfy the Indians for the lands we possess which detainure we fully conseive has so exasperated them that they have actually committed hostilities upon us \& we are alone impeled to defend ourselves from these raviges. 
stitution for the new state. ${ }^{7}$ In accordance with the provisions of this Constitution an election was held to choose members of the General Assembly, which met in March, 1785, and elected a Governor. ${ }^{8}$ A second meeting of the General Assembly was held on August 1st and affirmed a call for a convention, to be held in November, for the purpose of adopting or altering the Constitution of December, $1784 .^{9}$ When the convention met, a committee headed by Samuel Houston, a clergyman, presented for consideration the draft of a Constitution different from the provisional one previously adopted. ${ }^{10}$ According to the proposed draft the name of the state was to be "Frankland." 11 This draft was rejected and the convention adopted the provisional Constitution of $1784 .^{12}$

Although the name "Frankland" was used in the proposed draft of November, 1785, it was never adopted as the name of the state, which was always "Franklin." The Constitution of 1784 used the name "Franklin" consistently ${ }^{13}$ and there is conclusive evidence that the state

"3rdly. The resolutions of Congress held out from time to time incouraging the erection of New States have appeared to us ample incouragement.-

"4thly. Our local situation is such that we not only apprehend that we should be separated from North Carolina; but almost evrry sensible disinterested traviler has declared it incompatible with our Interest to belong in union with the Eastern part of the State for we are not only far removed from the Eastern part of North Carolina. But separated from them by high \& almost impasable mountains which naturally divide us from them have proved to us that our interest is also in many respects distinct from the inhabitants on the other side \& much injured by an union with them.

"5th. And lastly we Unanimously agree that our lives, liberties and Prosperity can be more secure \& our happiness much better propagated by our separation \& consiquently that it is our duty and unalienable right to form ourselves into a new Independent State-."

" A member rose and made some remarks on the variety of opinions offered, for and against a separation, and taking from his pocket a volume containing the Declaration of Independence by the colonies in 1776, commented upon the reasons which induced their separation from England, on account of their local situation, etc., and attempted to show that a number of the reasons they had for declaring independence, applied to the counties here represented by their deputies." "Manuscript of Rev. Samuel Houston, quoted in Ramsey, op. cit. supra note 5, at 287.

7. Willians, op. cit. silpra note 4 , at 42 .

8. Id. at 55. The Governor was John Sevier. Ibid. Sevier was a delegate to the convention of December, 1784.

On May 16, 1785 the State of Franklin petitioned the Continental Congress to admit the state to the "federal union," but this was not granted. Jefferson favored the petition. Williams, op. cit. supra note 4 , at $79,81,83$.

9. Id. at 88 .

10. Id. at 92 .

11. The Provisional Constitution of Frankland, 1 Am. Hist. Mag. 48 (1896).

12. Williarss, op. cit. supra note 4, at 92; Alden, The State of Franklin, 8 Ax. HIST. REv. 271, 275 (1902).

13. The Declaration of Rights was made by "the representatives of the Freemen of the State of Franklin." The Great Seal was that of "the State of Franklin." Sec. 17. All commissions were to be in "the name of the State of Franklin." Sec. 36. 
was so named in honor of Benjamin Franklin. A report of the debate regarding the naming of the state was as follows:

"A variety of names was proposed for the new commonwealth. Some were for calling it Franklin in honor of Benjamin Franklin, of Philadelphia; others, Frankland, as the land of freemen. But it was decided by a majority (small) in favour of calling it Franklin." 14

One of the leaders in the movement for the establishment of the state, William Cocke, wrote to Benjamin Franklin as follows:

"Sir.

State of Franklin 15th June 1786

"I make no doubt but You have heard that the good People of this Country have declared themselves a Separate State from North Carolina, and as a Testimony of The High Esteem they have for the many Important and Faithfull Services You have rendered Your Country, to Commemorate You, they have Call'd the Name of their State after You. . . ."

"Your most obeidt Hble Servt. "W" Cocke" 15

The Constitution of 1784 was never printed ${ }^{16}$ and there was no information regarding the existence of the written draft until 1904, when it was found in the office of the Insurance Commissioner of North Carolina in the capitol at Raleigh. ${ }^{17}$ The indications are that it was written by John Sevier. The Constitution included a Declaration of Rights and a plan of Government.

The Declaration of Rights contained twenty-five sections, six of which were as follows:

14. Letter from Rev. Samuel Houston to J. G. M. Ramsey, March 20, 1838. RAMLSEY, op. cit. supre note 5 , at 324 .

"The fitting and graceful as well as politic thing to have done was to give to the new commonwealth the name of 'Jefferson' in honor of him who, beyond all other statesmen of his time, embodied in his personality the spirit of independence and friendliness toward western aspirations." Willrams, op. cit. supra note 4 , at 84 .

15. 10 Smxth, Writings of Benjamin Frankitn 483 (1907).

It has been stated that the name of the state was "Frankland," 6 BANCroFT, History of THE UNITED STATES 460 (1884). It has also been stated that in the Constitution of 1784 the state was named "Frankland," but that this was later changed to "Franklin." Nevins, The American States During aNd After the RevoluTION 668 (1924).

16. "At that day, there was no printing press nearer than Richmond, Newbern or Charleston." RAMSEx, op. cit. supra note 5, at 379.

17. An article containing an account of the finding of the written Constitution and the text of the Constitution itself appeared in the Charlotte Daily Observer of September 25, 1904. The management of this newspaper generously sent the writer a photostatic copy of this article. The text of the Constitution, also based on the article in the Observer, was published in 1904. The Constitution of the State of Franklir, 9 AM. Hist. MaG. 399 (1904). 
1st Sec. That all Political power is vested in \& derived from the people only-

2nd Sec. That the people of this State ought to have the sole \& exclusive right of regulating the Internal Government thereof-

$3 \mathrm{~d}$ Sec. That no man or set of men, are intitled to exclusive or seperate Emoluments or Privileges from the community. But in consideration of Public services-

4th Sect. That the Legislature, executive, \& Supreme Judicial Powers of Government ought to be forever separate \& distinct from each other.-

5th Sect. That all powers of suspending laws or the execution of laws, by any authority without the consent of the Representatives of the People is injurious to their Rights \& ought not to be exercised.-

25 th Sect. That the people have a right by the Representatives to enact laws to encourage Virtue \& Suppress vice and immorality.

Most of the provisions of the body of the Constitution followed those of North Carolina. Thus the legislative authority in each state was vested in a Senate and House of Commons, comprising the General Assembly. ${ }^{18}$ The requirements for membership in these bodies, however, differed in one particular. In North Carolina it was required that each Senator must possess at least three hundred acres of land in fee and each member of the House of Commons, one hundred acres. ${ }^{19}$ In Franklin the requirement for Senator was one hundred acres and it was not necessary that a member of the House of Commons possess any land. ${ }^{20}$ In each state the privilege of voting for Senator was restricted to freemen who possessed fifty acres of land; ${ }^{21}$ and only freemen who had paid public taxes could vote for a member of the House of Commons. ${ }^{22}$

In both states it was provided that the General Assembly by joint vote of both Houses should elect the Governor, the Attorney General and Judges of the Supreme Court. ${ }^{23}$ In North Carolina it was required that the Governor have a freehold in lands above the value of one thousand pounds, ${ }^{24}$ while in Franklin a freehold of the value of two hundred and fifty pounds was sufficient. ${ }^{25}$ In both states the General Assembly
18. N.C., $\S 1 ;$ Frank., $\S 1$.
19. N.C., $\$ \S 5$ and 6 .
20. Frank., $\S \S 5$ and 6 .
21. $\S 7$.
22. $\S 8$.
23. $\$ \$ 13$ and 15.
24. N.C., \$15.
25. Frank., § 15 . 
was authorized to appoint a Council of State to advise the Governor. ${ }^{28}$ Both Constitutions provided that no minister of the gospel was eligible for membership in the General Assembly or Council of State while continuing to exercise his pastoral function. ${ }^{27}$ The following section was included in both Constitutions:

"A school or schools shall be established by the legislature for the convenient instruction of youth, with such salaries to the masters paid by the public, as may enable them to instruct at low prices; and all useful learning shall be duly encouraged and promoted in one or more Universities." 28

The draft of the "Frankland" Constitution, ${ }^{29}$ which was rejected by the convention, ${ }^{30}$ was in large measure the same as the provisional Constitution of 1784 . The most important differences were the provisions of the "Frankland" Constitution that (a) the legislative power should be vested in a single chamber, the House of Representatives, ${ }^{\text {B1 }}$ (b) "no attorney of law or doctor of physic," as well as no minister of the gospel, was eligible for membership in this body, ${ }^{32}$ (c) all bills of a public or general nature should be printed for the consideration of the voters before the third reading, ${ }^{33}$ (d) the Governor, should be elected by the voters of the state, ${ }^{34}$ and (e) "The privileges and benefit of the writ of Habeas Corpus shall be enjoyed in this commonwealth, in the most free, easy, cheap, expeditious and ample manner." ${ }^{35}$ It was also provided that no person should be eligible to serve in the House of Representatives or any other office of the civil government, "who is of an immoral character, or guilty of such flagrant enormities as drunkenness, gaming, profane swearing, lewdness, Sabbath breaking, and such like." 36 The provision regarding the establishment of a university was more specific than the corresponding section of the North Carolina and Franklin Constitutions, for it was stated that "the future

26. $\$ 16$.

27. $\S 31$.

28. $\$ 41$.

29. The "Frankland" Constitution was privately printed in Philadelphia and a copy is now in the possession of the Tennessee Historical Society. The text of the Constitution appears in 1 AM. Hist. MAG. 48 (1896).

30. Ramsey, op. cit. supra note 5 , at 323 .

31. \$ 1. It has been stated that the Constitution adopted by the State of Franklin provided for a "unicameral legislature." Nevins, op. cit. stupra note 15 , at 674 . This provision was in the "Frankland Constitution," which was rejected, not in the "Franklin Constitution," which was adopted.

32. §3.

33. $\$ 7$.

34. $\$ 11$.

35. $\$ 44$.

36. $\$ 3$. 
legislature shall erect, before the year seventeen hundred and eightyseven, one University, which shall be near the centre of this state and not in a city or town." 37

From the start there was dissension among the leaders of Franklin which steadily increased..$^{38}$ At the same time North Carolina consistently refused to recognize the new state and in 1787 appointed officials to operate within its territory. "County courts were held in the same counties under both governments; the militia was called out by officers appointed by both; laws were passed by both Assemblies, and taxes were laid by the authority of both States." 39 As a result of the dissension within its territory and of the pressure exerted by North Carolina the government of Franklin ceased to operate in the year 1788 and Franklin as a separate state ceased to exist. ${ }^{40}$ In 1790 the portion of North Carolina west of the mountains was definitely ceded to the United States ${ }^{41}$ and in 1796 was admitted to the Union as the State of Tennessee.

A historian, writing a century ago, stated the following regarding the State of Franklin:

"In all that was done in Franklin, we are unable to detect any tendency to radicalism. In their warmest aspirations for selfgovernment and independence, there can not be found one feature of modern agrarianism or the prostration of all law, but only a disposition to protect themselves from violence and aggression and possible danger to their rights." 42

\section{Indian Stream Republic}

The Revolutionary War was formally ended by the Treaty of Paris in 1783 , but many matters of dispute remained unsettled. ${ }^{43}$ One of the

37. $\$ 32$.

38. NeviNs, op. cit. suprot note 15 , at 669 .

39. Haywood, Civil and Political History of Tennessee 173 (1823).

40. AberNethy, op. cit. supra note 1 , at 89 .

On April 9, 1787 Governor Sevier wrote a letter to Benjamin Franklin in which he described the antagonism of North Carolina toward the State of Franklin. One of the paragraphs of this letter was as follows:

"I have thus given your Excellency the outlines of our past and present situation, and beg leave to inform you, that, from your known patriotic and benevolent disposition, as also your great experience and wisdom, I am, by and with the advice of our Council of State, induced to make this application, that should you, from this simple statement of the several occurrences, think our cause so laudable, as to give us your approbation, you would be pleased to condescend to write on the subject. And any advice, instruction, or encouragement, you think we shall deserve, will be acknowledged in the most grateful manner." SMYTH, op. cit. supra note 15 , at 486.

41. Nevins, op. cit. supra note 15 , at 671 .

42. RaArsey, op. cit. supra note 5 , at 440 .

43. It was not until 1795 that the last British soldiers were recalled from the territory that had been assigned to the United States by the treaty of peace. 3 Cenanating, History of the United States 373 (1926). 
most important of these, the "Northeastern Boundary" between Canada and the states of New Hampshire and Maine, ${ }^{44}$ was not determined until the Webster-Ashburton Treaty in 1842.

Near the close of the eighteenth century a few pioneers settled in the region of Indian Stream, ${ }^{45}$ a tributary of the Connecticut River. This region was claimed by both Great Britain and the United States, but neither exercised authority over it. In 1820 the state of New Hampshire asserted title to and jurisdiction over this territory, ${ }^{46}$ but did not interfere with the local government which was administered by the proprietors. ${ }^{47}$

On June 11, 1832 the "inhabitants" of the Indian Stream territory met and authorized a committee to draft a Constitution for the government of this territory until such time as a boundary was established between Canada and the United States. ${ }^{48}$ On July 9th of the same year the Constitution prepared by the committee was adopted ${ }^{49}$ and the Indian Stream Republic with a population of about 400 persons ${ }^{50}$ was thereby established.

44. Until 1819 the territory, which is now the state of Maine, was a part of Massachusetts. (1915).

45. Showerman, The Indian Stream Republic, 11 CoLcect. N.H. Hist. Soc'y 11

46. Parker, C.J. in Bedel v. Loomis, 11 N.H. 9, 15 (1840).

47. Showerman, supra note 45 , at 30 .

48. Minutes of meeting. Id. at 55.

49. Id. at 56. The preamble of the Constitution was in part as follows:

"WhEREAS we the inhabitants of the tract of land situated between Hall's Stream and the stream issueing from Lake Connecticut being the disputed tract of country near the head of Connecticut River which is claimed by the United States and Great Britain respectively and generally known by the name of Indian Stream and whereas we are deprived of the protection of the Laws of any Government but that of our own until such time as the Boundary line between the two Governments shall be established, and the time in which that will take place is to us unknown, and whereas it is our ardent desire to live in peace, Harmony and good order \& considering that these great and good objects cannot be fully enjoyed without some wholesome rules, regulations, or code of laws, and considering it the unalienable right of all people situated as we are wherever in the course of providence their lot is cast, and a privilege which they are in duty bound to improve to strive by all laudable means to take and adopt such measures as shall be best calculated to promote peace and good order in society among themselves while in their present state as well as to prepare them for useful citizens should they hereafter become a constituent part of some other government ....

"Therefore resolved that to preserve union among ourselves, establish Justice, ensure domestic tranquility provide for our common security and defence and secure the important Blessings of civilized society, We do ordain and establish this Constitution and the principles of Government therein contained for our future guide and direction in forming and enforcing Laws for the government of the territory of Indian Stream."

50. The population in 1835 was four hundred and fourteen. Audet, La République d'Indian Stream, 12 Proc. and Transact., Royal Soc'y of Canada 119, 124 (2d ser. 1906). The number of voters at this time was seventy-five. Showerman, supra note 45 , at 97 . 
The provisions of the Bill of Rights ${ }^{51}$ follow in general those of the New Hampshire Constitution of 1784 , but two additional and two modified articles are thought to be of interest. The additional articles are the following:

"Article 6th. Every subject of the government has a right to a certain remedy by having recourse to the Laws for all injuries he may receive in his person, property or character; to obtain right and justice freely and completely, without any denial, promptly and without delay conformably to the Laws. ${ }^{62}$

"Article 13th. Man being originally formed by his Creator for society and social intercourse \& for mutually aiding, assisting and defending each other and promoting their mutual welfare and happiness therefore all societies of men placed by circumstances of fortune without the Jurisdiction or control of any other society or Government have a right to unite together and institute such government for the regulation of their society as they deem most conducive to the general good, and where a large majority of the people so situated unite together and establish a government the minority of right ought to submit to the majority and be controlled by them." 58

The two modified articles are as follows:

"Article 2nd. Every man has a natural, essential, and unalienable right to worship God according to the dictates of his own conscience and reason, and is not accountable to any human tribunal, for his religious opinions or practices, provided he does not encroach upon the civil or religious rights of others. ${ }^{54}$

"Article 3rd. All men have certain natural and essential civil rights, among which are the enjoying and defending life and liberty; acquiring, possessing, \& protecting property; and in a word of seeking and obtaining happiness. Hence arises the right of controlling those vicious members of society, who invade the rights of others." 55

The New Hampshire provision that "No person who is conscientiously scrupulous about the lawfulness of bearing arms, shall be compelled thereto, provided he will pay an equivalent" 56 was not included in the Indian Stream Bill of Rights.

51. "A Bill of Rights followed setting out general principles and rules, in language as eloquent as if it had been made for the governance of millions." Reid, The Indiant Stream Territory, 34 Proc. AND TRANSACT., RoYal Soc'y of Canada 143,150 (3d ser. 1940).

52. Showerman, supra note 45 , at 59 .

53. Id. at 60 .

54. Id. at 58. Emphasis added. The qualifying clause in the New Hampshire Bill of Rights was, "provided he doth not disturb the public peace, or disturb others, in their religious worship." N.H., Bill of Rights, art. 5 (1784).

55. Emphasis added. The last sentence of the article does not appear in the corresponding section of the New Hampshire Bill of Rights, art. 2 (1784).

56. N.H., Bill of Rights, art. 13 (1784). 
The form of government established by the Indian Stream Constitution was unique. The legislative power was vested in a Council and Assembly. ${ }^{57}$ Every adult male inhabitant, who had been a resident for three months, was admitted as a member of the Assembly upon taking the required oath. ${ }^{58}$ The Council, which consisted of five members, chosen annually by vote of the Assembly, had the sole power to initiate legislation. ${ }^{59}$ Authority was given the Council to command the militia ${ }^{60}$ and to exercise clemency in the case of persons convicted of crime. ${ }^{01}$ The Council also constituted a "high court of error" with appellate jurisdiction. ${ }^{62}$ It will be noted that the Council exercised at the same time legislative, executive and judicial powers. ${ }^{\text {es }}$ Luther Parker, while serving as a member of the Council, was given the honorary title of "President of the Republic." 64

That the framers of the Constitution were not content simply to establish a form of government is shown by the following provision:

"Knowledge and Learning generally diffused through a community being essential for the preservation of a free government, and spreading the opportunities and advantages of education through the various parts of the community being highly conducive to promote this end it shall be the duty of the Legislators and Magistrates in all future periods of this Government to cherish the interest of Literature and sciences and public schools, to countenance and inculcate the principles of humanity and general benevolence, public \& private charity, industry \& economy, honesty and punctuality, sincerity \& sobriety, and all social affections and generous sentiments among the people." 65

57. Showerman, supra note 45 , at 60 .

58. Id. at 61 . The required oath was as follows: "I solemnly swear that to the best of my power and ability I will support inviolate the constitution and laws of Indian Stream. So help me God." Ibid.

59. Id. at 61,62 .

60. Id. at 62 .

61. Id. at 63. The executive department made no provision for a jail. "The sheriff was ordered 'to confine him or them in his own dwelling house, outhouses, or any building by him provided, or by any of the inhabitants of Indian Stream afforded, until the sentence of the court before whom the respondent shall be convicted.' At times, a huge iron, potash kettle was inverted on a flat rock near the sheriff's house, and the prisoner confined underneath, leaving space for air." MARSHALx, INDLAN Stream Republic and the Indian Streand War 23 (pamph. 1935).

62. Showerman, stipra note 45 , at 63 .

63. The New Hampshire Constitution provided that "In the Government of this State, the three essential powers thereof, to wit, the Legislative, Executive, and Judicial, ought to be kept as separate from, and independent of, each other as the nature of a free government will admit, or as is consistent with that chain of connection that binds the whole fabric of the Constitution in one indissoluble bond of union and amity." Bill of Rights, art. 37 (1784).

64. Little 'Lost Republic' Almost Forgotten, N.Y. Times, Mar. 8, 1925, Sect. 7, p. 17 , col. 1.

65. Showerman, supra note 45 , at 64 . "Taken as a whole, it [the Constitution] is a document which reflects credit on the intelligence and moral standards of the members of the little frontier settlement." Reid, supra note 51 , at 150 . 
Although the population of the Indian Stream Republic was ridiculously small it existed as an independent country for four years. ${ }^{68}$ "Courts of Justice" were established in 1832 by the Assembly, which also passed an act for summoning jurors. In 1833 the Assembly enacted legislation providing for the assessing and collecting of taxes, for laying out highways and for the support of schools. The Assembly of 1834 passed inter alia an act regulating marriages and an act to prevent vexatious suits at law. In 1835 statutes to protect officers in their official duties and to compel the attendance of witnesses were enacted. ${ }^{67}$

During the period of the Republic's existence there was friction with New Hampshire which at various times attempted to serve warrants in its territory. ${ }^{68}$ In 1835 as a result of disturbances troops were sent there by the Adjutant General of New Hampshire. ${ }^{69}$ They were removed in the early part of $18.36^{70}$ and on April 2nd the citizens of the Indian Stream Republic approved a resolution "that New Hampshire has a right to exercise an unconditional control over the territory of Indian Stream." 71 This region is south of the international boundary established by the Webster-Ashburton Treaty and consequently is within the State of New Hampshire. ${ }^{72}$

66. Audet, supra note 50, at 120; Aldrich, Our Northern Boundary, 2 N.H. Hist. Soc'y Proc. 367, 384 (1888).

"The United States Government took Indian Stream at its word and began to levy customs duties on all goods going into and coming out of the territory, much to the displeasure of the farming folk." Little 'Lost Republic' Almost Forgotten, sipra note 64 .

67. Showerman, supra note 45 , at $69,72,77,81,90$.

68. $I d$. at 93. On September 2, 1834 "the council of Indian Stream addressed a memorial to the Attorney General of the United States setting forth their claim to be under the jurisdiction of the general government, but not under that of the state of New Hampshire." Id. at 94. The Attorney General replied as follows: "If you are within the limits of the United States, as has always been maintained by this government, it is because you are within the limits of the state of New Hampshire." Id. at 95.

69. Id. at 107 .

70. $I d$. at 109.

71. Id. at 110. In June, 1836 the Legislature of New Hampshire appointed commissioners to investigate conditions in the Indian Stream region. The commissioners reported as follows:

"The commissioners, in conclusion, are happy in being able to inform Your Excellency and the legislature that the inhabitants of this section of our state are now in as quiet and peaceable condition, as free from internal commotion or foreign interference, as any portion of the state whatever. The citizens there, who were friendly to the preservation of good order and the wholesome administration of the laws, and who had begun to apprehend that they were neglected, have been assured that the protecting energies of the state are extended to all within her borders, while the lawless and the vicious have been made to feel that their remote situation affords no sanctuary for crime." Id. at 175 .

72. The territory of Indian Stream is "almost identical with the present township of Pittsburg, Coös County." Id. at 8. 


\section{State of Deseret}

In the year 1847 an advance group of Mormons moved into the valley of Great Salt Lake. ${ }^{73}$ The population of the region increased rapidly by the arrival of other Mormon immigrants. For nearly two years the population was under the sole control of the ecclesiastical leaders, ${ }^{74}$ but on March 5, 1849 "the inhabitants of that portion' of Upper California lying east of the Sierra Nevada Mountains" assembled in a convention and established the State of Deseret. ${ }^{75}$ A Constitution was proposed and adopted. ${ }^{76}$

The Declaration of Rights of the Constitution followed the usual pattern but the following section on religious freedom is of interest:

"All men shall have a natural and inalienable right to worship God, according to the dictates of their own consciences; and the General Assembly shall make no law respecting an establishment of Religion, or of prohibiting the free exercise thereof, or disturb any person in his religious worship or sentiments; provided he does not disturb the public peace, nor obstruct others in their religious worship: and all persons, demeaning themselves peaceably, as good members of the State, shall be equally under the protection of the laws; and no subordination or preference of any one sect or denomination to another, shall ever be established by law; nor shall any religious test be ever required for any office of trust under this State." 77

The Constitution provided that the Government should be divided into "three distinct departments: Legislative, Executive, and Judiciary." 78 The legislative authority was vested in a General Assembly,

73. BANCROFT, History OF UTAH 262 (1889).

74. Id. at 439.

75. Id. at 440. "Deseret" means "honeybee." Book of Mormon, Estrer, II, 3. This explains why Utah is now called the "Beehive State." ROMNEY, THE STORY OF DESERET 103 (1948).

76. The State of Deseret, 8 UTAн HIST. Q. 86 (1940). The boundaries of the state, as described in the Constitution, comprised nearly all of the present State of Utah, most of Arizona and Nevada and portions of Wyoming, Colorado, New Mexico, California, Idaho and Oregon. Ibid. The extent of the state's territory was estimated at 490,000 square miles. NEFF, History OF UTA\# 117 (1940).

The preamble of the Constitution was in part as follows:

"Whereas a large number of Citizens of the United States, before and since the Treaty of Peace with the Republic of Mexico, emigrated to and settled in that portion of the Territory of the United States, lying west of the Rocky Mountains, and in the Great Interior Basin of Upper California; and

"Whereas, by reason of said treaty, all civil organization, originating from the Republic of Mexico became abrogated; and

"Whereas, the Congress of the United States has failed to provide a form of Civil Government for the Territory so acquired, or any portion thereof. . . ." The State of Deseret, supra at 156.

77. Sec. 3.

78. Art. 1. 
consisting of a Senate and House of Representatives, both to be elected by the people, ${ }^{70}$ who also elected the Governor. ${ }^{80}$ The judges were to be elected by joint vote of both Houses of the General Assembly. ${ }^{81}$ One unusual feature of the Constitution was that, except for the Governor, ${ }^{82}$ no provision was made for the compensation of officials.

An election was held one week after the Constitution was adopted and Brigham Young was elected Governor. Early in July of the same year the Assembly met and adopted a memorial requesting Congress to admit the State of Deseret to the Union. ${ }^{83}$ This request was rejected on January 28, $1850,{ }^{84}$ and on September 7 th Congress established a portion of the territory of Deseret as a territory under the name of Utah. ${ }^{85}$

The General Assembly of Deseret, which continued to operate until April 5, 1851, adopted in January of that year a criminal code with some interesting features. ${ }^{86}$ It was provided that in the case of aggravated assault and false imprisonment the convicted defendant in addition to a penalty of fine or imprisonment should pay the victim for all damages sustained. ${ }^{87}$ Upon a conviction for larceny or obtaining property by false pretenses four fold damages were to be paid. ${ }^{88}$ The punishment for fornication or seduction by either a man or a woman

79. Art. $2, \S 1$.

80. Art. 5, $\$ 1$.

81. Art. $4, \S 3$.

82. Art. $3, \S 12$.

83. State of Deseret, supra note 76, at 89.

84. BANCROFT, op. cit. supra note 73 , at 452 .

"That the Mormons, not designing to pass through the years of their political minority, should now ask admission as a state, and meanwhile constitute themselves a free and independent community, an imperium in imperio, issuing full-fledged, as did Minerva from the cranium of Jove, into the society of republics, was a proceeding that of course failed to meet with the approval of Congress." Id. at 451 .

85. Id. at 453. The Mormons objected to the name of Utah, which "was one of the several forms of the name for the Ute Indians, who were regarded by the Mormons with a little fear, more pity, and a great deal of contempt." State of Deseret, supra note 76, at 126.

"But after the organization of the territorial government of Utah under the act of Congress, the legislative assembly of the Territory passed the following resolution: 'Resolved, by the Legislative Assembly of the Territory of Utah, That the laws heretofore passed by the provisional government of the State of Deseret, and which do not conflict with the organic act of said Territory, be and the same are hereby declared to be legal and in full force and virtue, and shall so remain until superseded by the action of the legislative assembly of the Territory of Utah'. This resolution was approved October 4, 1851." Bradley, $J$. in The Late Corporation of the Church of Jesus Christ of Latter-Day Saints v. United States, 136 U.S. 1, 45 (1889).

86. State of Deseret, supra note 76, at 213.

87. $\$ \S 29$ and 32 . In France a criminal and a civil action may be tried together and a convicted defendant compelled to pay damages to the person injured, as well as to undergo a punishment imposed by the court. Keedy, Preliminary Investigation of Crime in France, 88 U. of PA. L. REv. 385, 414 (1940).

$88 . \S 28$ and 33 . 
was imprisonment at hard labor for a term not exceeding five years and a fine not exceeding five thousand dollars. "Private damages" could also be awarded by the court. The penalty for murder was death "by being shot, hung, or beheaded." ${ }^{89}$ No record of an execution by beheading was found.

89. $\$ 10$. Emphasis added. This provision was incorporated in a statute of the Territory of Utah approved March 6, 1872. This entire statute was repealed by the Penal Code of 1876, §399.

So far as the present writer is aware this is the only instance in this country of beheading being authorized as a method of capital punishment.

The last person to be executed by beheading in Great Britain was Iord Lovat, on April 9, 1747. Scott, The History of Capital Punishment 179 (1950). 